\title{
Transpiration-use efficiency of young cactus pear plants (Opuntia ficus-indica L.)
}

\author{
Cristián Kremer ${ }^{1}$, Carlos Faúndez², Víctor Beyá-Marshall ${ }^{3}$, Nicolas Franck ${ }^{3 \dagger}$, \\ and Víctor Muñoz-Aravena ${ }^{3}$ \\ ${ }^{1}$ Universidad de Chile, Facultad de Ciencias Agronómicas, Departamento de Ingeniería y Suelos. Santiago, \\ Chile. \\ ${ }^{2}$ Universidad de O'Higgins, Instituto de Ciencias Agroalimentarias, Animales y Ambientales. San \\ Fernando, Chile \\ ${ }^{3}$ Universidad de Chile, Facultad de Ciencias Agronómicas, Departamento de Producción Agrícola. \\ Santiago, Chile. \\ 'Deceased 20 October 2017
}

\begin{abstract}
C. Kremer, C. Faúndez, V. Beyá-Marshall, N. Franck, and V. Muñoz-Aravena. 2021. Transpiration-use efficiency of young cactus pear plants (Opuntia ficus-indica L.). Int. J. Agric. Nat. Resour. 115-124. Opuntia ficus-indica is a versatile crop that is resilient to drought, making it perfect for semiarid to arid zones. However, the lack of knowledge associated with its benefits and the lack of simple crop growth simulation models to determine its potential development, among others, has prevented its expansion. Transpiration-use efficiency $(w)$ has been used to evaluate crop performance under different water supplies; however, the lack of consistency in $w$ values under different environmental conditions has impeded its use as a transferable parameter. To overcome this problem, $w$ is estimated through the normalized water-use efficiency $\left(k_{D a}\right)$ and the vapor pressure deficit $(D a)$ as $w=k_{D a} D_{a}^{-1}$, where $k_{D a}$ is a crop-dependent parameter. Therefore, the goals of this research were (i) to determine $w$ and $k_{D a}$ in young plants of Opuntia ficus-indica and (ii) to compare the obtained parameters with values from other species. The $w$ and $k_{D a}$ results were $18.57\left(\mathrm{~g} \mathrm{~kg}^{-1}\right)$ and $6.48\left(\mathrm{~g} \mathrm{kPa} \mathrm{kg}^{-1}\right)$, respectively. Here, $w$ was more than two to six times the value for traditional cereals (maize, rice, wheat), while $k_{D a}$ was larger than that of most $\mathrm{C} 3$ crops and fell in the range for $\mathrm{C} 4$ and CAM crops. This is the first study that explicitly determines $k_{D a}$ for Opuntia ficus-indica; hence, more research should be carried out on its estimation, including under different agroclimatic conditions and in later stages of development. As a first approximation, the parameters obtained here can be used as a simple model to estimate yield projections of Opuntia ficus-indica.
\end{abstract}

Keywords: Arid zone agriculture, CAM, crops adapted to drought, simple crop growth models.

\section{Introduction}

Chile is under a serious water availability crisis, especially in semiarid to arid climate areas (central-northern zones of the country). In these

Received May 04, 2020. Accepted Jul 14, 2021

Corresponding author: ckremer@uchile.cl zones, the demand/availability ratio for water is affected by rainfall scarcity in the last ten years and by the high demand for water among stakeholders (Garreaud et al., 2017). In this scenario, the planting of fruit trees can be expanded via crops with low water requirements, good profitability and resistance to drought, such as Opuntia 
ficus-indica (cactus pear) (Sudzuki et al., 1993). Opuntia ficus-indica is a versatile crassulacean acid metabolism (CAM) species with diverse uses, such as fresh fruit and biofuel (Sáenz et al., 2006; Bernab \& Lamas, 2011). This plant is also resilient to drought (Inglese et al., 2017), making it an excellent candidate for semiarid to arid zones. However, in Chile, according to the last agricultural and forestry census carried out in 2020, the area under cactus pear production was close to 596 ha, which incentivizes its expansion through the development of technical and scientific information available to farmers, especially information that allows them to make more efficient use of their water resources and to determine early indicators of the potential yield of cactus pear under different agroclimatic conditions.

Transpiration-based models of crop productivity, such as transpiration-use efficiency $(w)$, defined as the amount of biomass expressed as dry matter produced for a unit of water transpired by a crop (Tanner \& Sinclair, 1983), can be readily applied to a large number of crop species across the range of climatic conditions where these crops are grown. Katerji et al. (2008) pointed out that there are two approaches: an ecophysiological approach based on the analysis of the relationship between photosynthesis and transpiration per unit of leaf area at a given moment, called instantaneous water-use efficiency $\left(w_{i}\right)$, and a seasonal approach based on the concepts of water consumption and biomass production ( $w$ ). However, the lack of consistency in $w$ values for a species under different environmental conditions has not allowed its use as a simple crop simulation model (Katerji et al., 2008, Kremer \& Stöckle., 2012, Kremer et al., 2020). Among the reasons for this lack of consistency are experimental and methodological errors, agronomic management (Faustino et al., 2011), and major climate differences (Tanner \& Sinclair, 1983; Kremer et al., 2008). On the other hand, simpler models have been developed to decrease the variability of $w$ concerning climatic differences between sites, such as $w=k_{D a} D a^{-1}$, where $D a$ corresponds to the vapor pressure deficit of the zone and $k_{D a}$ is a crop-dependent parameter, also known as normalized water-use efficiency. Normalization by $D a$ would correct the climatic variations in $w$, while $k_{D a}$ would remain reasonably constant in different climatic zones (Condon, 1993; Kemanian et al., 2005; Steduto \& Albrizio, 2005; Kremer et al., 2008).

Consequently, due to the affinity of the cactus pear fruit tree for growth in arid/semiarid regions and the lack of simple crop growth simulation models to determine its potential yield and development in different environments, the main objective of this research was to determine its $w$ and $k_{D a}$ parameters and to compare these values with data obtained for other species based on the literature.

\section{Material and methods}

Site, plant material and agronomic management

The experiment was performed at the experimental station "Las Cardas" of the University of Chile, Coquimbo region, Elqui Province $\left(30^{\circ} 17^{\prime} \mathrm{S}\right.$, $71^{\circ} 15^{\prime} \mathrm{W}, 436$ m.a.s). The zone's climate is temperate, arid Mediterranean with precipitation of 100 to $150 \mathrm{~mm}$ year ${ }^{-1}$ in winter. The annual average temperature is $14.4^{\circ} \mathrm{C}$.

Forty-eight one-year-old cactus pear plants of ecotype "Blanco" were planted in $55 \mathrm{~L}$ pots $(0.45$ $\mathrm{m}$ in internal diameter and $0.5 \mathrm{~m}$ in height, Figure 1A) filled with $2 \mathrm{~mm}$ expanded perlite (bulk density: $0.155 \mathrm{Mg} \mathrm{m}^{-3}$, water holding capacity base volume: $28 \%$ ) up to a height of $40 \mathrm{~cm}$. A layer of $4.5 \mathrm{~kg}$ of gravel was placed in the base of each pot to allow atmospheric seepage flow, and a $0.1 \mathrm{~mm}$ thick black polyethylene plastic was placed on the surface of each pot to avoid water loss by evaporation. Three drippers ( $2 \mathrm{Lh}$ $\left.{ }^{1}\right)$ were used to irrigate. Irrigation was triggered when the water content was close to $70 \%$ of the water-holding capacity (WHC). The pots were weighed every two days using a scale to check the water content parameters (Izetta, mod. PK60, 
China). Irrigation was stopped when $95 \%$ of the WHC was reached. The pots were arranged in a row with a north-south orientation (Figure 1B), so all of them received similar light radiation. Other management practices, such as fertilization and pest control, were performed to ensure optimal development. Data were collected over a 503-day-long period that started on December 13, 2009, and ended on April 30, 2011.

\section{Biomass}

Four complete plants were extracted approximately every 40 days until 10/25/2010, and then two complete plants were extracted until the end of the trial (Figure 1B). In both cases, the fresh weight $(F M)$ and the dry weight $(D M)$ of the plants were determined using precise scales (Precisa mod. 3100c; accuracy of $0.01 \mathrm{~g}$, Switzerland). To obtain $D M$, the plants were oven dried at $65{ }^{\circ} \mathrm{C}$ (Memmert model 800, Germany) until reaching a constant weight.

\section{Transpiration}

The transpired water was determined by mass lysimeters, where the unit to be weighed corresponded to each of the remaining $55 \mathrm{~L}$ pots at the end of each measurement interval. Crop transpiration was considered to be equal to the variation in the mass of the pot that occurred between each irrigation event once excess water was drained. For its determination, at the beginning of each measurement interval, a sufficient water load was applied to reach $95 \%$ of the WHC, and the water was allowed to drain freely for approximately 4 hours before pots were returned and weighed with a scale (Izetta, model PK60, China). At the end of the measurement interval and before watering, each pot was weighed again. Therefore, transpiration for the measurement interval (Ati) was determined as follows:

$A t i=M a i-M b i-E i+G f$

where Mai $(\mathrm{kg})$ is the pot mass after irrigation, $M b i(\mathrm{~kg})$ is the pot mass before irrigation, $E i$ is the loss by evaporation and $G f(\mathrm{~kg})$ is the plant growth factor. The error produced in the estimation of transpiration by the increase in the plant's biomass over time was corrected once the study was finalized. The correction of $G f$ was determined through an exponential adjusted model of the total average $F M$ as a function of time; with this information, the $F M$ increment for the measurement interval was added to obtain Ati. Additionally, to avoid weight loss due to transpiration during drainage, water was applied to the plants in the morning due to their CAM metabolism. In turn, mass lysimeters were available under the same conditions as the previous ones but without plants to correct eventual losses due to evaporation. Daily
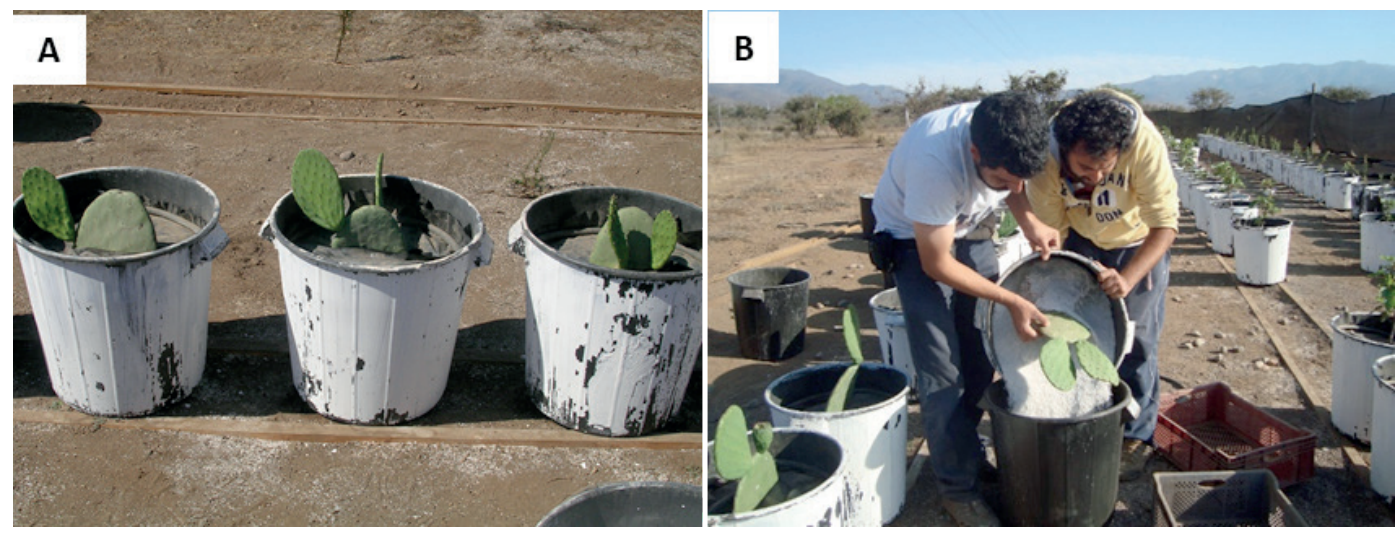

Figure 1. A: 55 L pots, B: Arrangement of pots in the north-south direction and plant extraction procedure. 
transpiration ( $T d$ ) was inferred as $A t i / \mathrm{n}$, where $\mathrm{n}$ is the number of days between each measurement interval "i". The cumulative transpiration $(T)$ was estimated as follows:

$T=\sum_{i=1}^{i=m} A t i$

\section{Transpiration-use efficiency (w)}

Transpiration-use efficiency $(w)$ was computed as the slope of the linear regression between the average cumulative $D M(\mathrm{~g})$ and the average cumulative $T(\mathrm{~kg})$ as follows (Tanner \& Sinclair, 1983; Condon, 1993; Kemanian et al., 2005; Steduto \& Albrizio., 2005; Kremer \& Stöckle, 2012; Kremer et al., 2008, 2020):

$w=\frac{d D M}{d T}$

where $w=$ Transpiration use efficiency $\left(\mathrm{g} \mathrm{kg}^{-1}\right), D M$ = cumulative dry matter $(\mathrm{g})$ and $T=$ cumulative transpiration $(\mathrm{kg})$.

\section{Normalized water-use efficiency $\left(k_{D d}\right)$}

The normalized water-use efficiency $k_{D a}\left(\mathrm{~g} \mathrm{kPa} \mathrm{kg}^{-1}\right)$ was estimated as the slope of the linear regression between the average cumulative $D M(\mathrm{~g})$ and the daily integration of the quotient between average $T d(\mathrm{~kg})$ and air vapor pressure deficit during the night (Td $D_{a n}{ }^{-1} ; \mathrm{kg} \mathrm{kPa}^{-1} ;$ Eq 4, Tanner \& Sinclair, 1983; Condon, 1993; Kemanian et al., 2005; Steduto \& Albrizio., 2005; Kremer \& Stöckle, 2012; Kremer et al., 2008, 2020) as follows:

$k_{D a}=\frac{d D M}{d\left(\frac{T d}{D a n}\right)}$

where $D M=$ cumulative dry matter (g), $T d=$ daily transpiration $(\mathrm{kg})$ and $D_{a n}=$ daily air vapor pressure deficit at night (kPa). To calculate $D_{a n}$, the maximum and minimum relative humidity $(\mathrm{RH}$ (max) and RH (min)) and maximum and minimum temperature $(\mathrm{T}(\max )$ and $\mathrm{T}(\mathrm{min}))$ during the night were used. The climatic variables were obtained from a weather station located $300 \mathrm{~m}$ away from the study site (Campbell Scientific, U.S.A.). The methodology for the computation of $D_{a n}$ is fully described in FAO-56 (2006).

\section{Statistical analysis}

A regression analysis was performed to obtain $w$ and $k_{D a}$ with INFOSTAT statistical software $(p<0.05)$. In both cases, the statistical significance of the $y$-axis interception was analyzed. Additionally, an exponential regression to obtain $G f$ was adjusted where the dependent variable was $F M$ and the independent variable was days after planting. The coefficient of determination $\left(\mathrm{R}^{2}\right)$ was used to evaluate the accuracy of these regressions.

\section{Results and discussion}

Figures 2 and 3 show the results obtained from the growth and transpired water tests. Exponential increases in both $D M$ and $F M$ was observed, which was also reflected by $T$ (Figure 2). The exponential adjustment of $G f$ (Figure 1, FM graph) showed a high coefficient of determination $\left(\mathrm{R}^{2}: 0.99\right)$, which gave confidence in its use for the estimation of $T$.

There is a lack of information about $w$ in CAM plants. The available information is mainly related to water-use efficiency (WUE), which includes evapotranspiration and, in some cases, gross irrigation, making it a poor parameter for transferability among climatically different sites and for comparison with our results. Figure 4 displays the results for $w$ and $k_{D a}$ for cactus pear plants. The interception with the y-axes was not statistically significant $(\mathrm{p}<0.05)$; therefore, both values start at zero. The value of $w$ obtained was $18.58 \mathrm{~g} \mathrm{~kg}^{-1}$, which is in the lower range of the values reported by Silva and Acevedo (1995, Table 1). This values is also approximately 2 to 4 times greater than the values reported for $\mathrm{C} 4$ crops such as maize and 

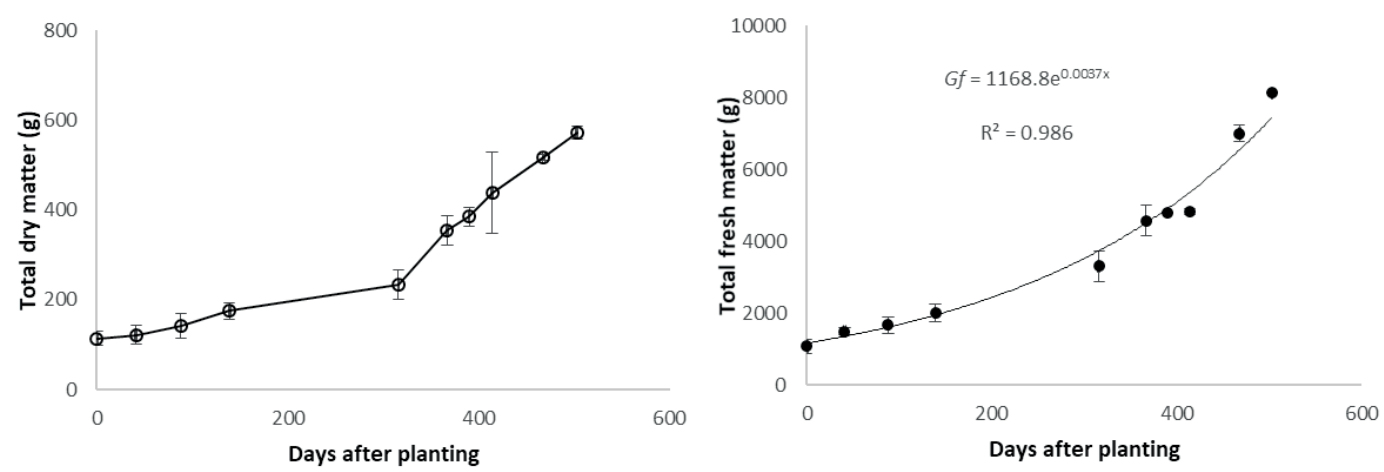

Figure 2. Cumulative dry matter $(D M)$ and fresh matter $(F M)$ during the whole trial. Dots represent the average weight, and error bars represent the standard deviation for each sample interval.

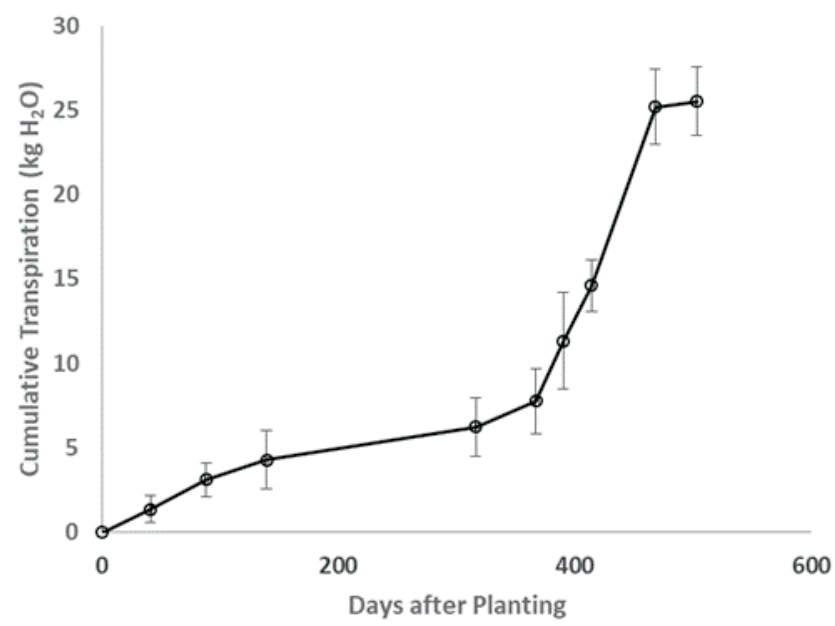

Figure 3. Cumulative transpiration during the whole trial. Dots represent the average transpiration, and error bars represent the standard deviation for each sample interval.

sorghum (Table 1) and up to 2 to 6 times greater than some values reported for $\mathrm{C} 3$ crops such as alfalfa, barley, wheat, rice and jatropha (Table 1). This result agrees with Nobel (2003) and his study on ecophysiology in cactus pears, where he concluded that CAM plants have a $w$ three times larger than that of highly productive $\mathrm{C} 4$ plants, such as maize or sugar cane, and 5 times larger than that of highly productive C3 plants, such as alfalfa, cotton or wheat. This higher efficiency was also noted by Carvajal et al. (2010), who presented a study on $\mathrm{CO}_{2}$ absorption ( $\mathrm{g}$ of $\mathrm{CO}_{2}$ fixed per $\mathrm{kg}$ of transpired $\mathrm{H}_{2} \mathrm{O}$ ) by $\mathrm{C} 3, \mathrm{C} 4$ and CAM plants. Their findings showed $\mathrm{CO}_{2}$ absorption rates of 1-3, 2-5 and 10-40 $\mathrm{g} \mathrm{kg}^{-1}$ for C3, C4 and CAM plants, respectively. Silva and
Acevedo (1995) and Nobel (2003) mentioned that one of the mechanisms that explains the higher $w$ of cactus pear with respect to $\mathrm{C} 3$ and $\mathrm{C} 4$ plants is related to its CAM metabolism, where the smallest difference in vapor pressure between the plant and the atmosphere during the night coincides with its period of maximum stomatal opening, decreasing its transpiration rate and consequently increasing $w$. In this study, we found that Dan was practically half of Dad (vapor pressure difference during the day) throughout the whole trial, which supports Noble's (2003) comments (Figure 5). Conversely, Felker and Han (1997) conducted an open-field experiment in Texas (USA) for four years using Opuntia ellisiana (CAM plant) to estimate $w$. They measured the biomass without 
including the roots and estimated the transpiration with indirect methods. They reported a $w$ value of $6.17 \mathrm{~g} \mathrm{~kg}^{-1}$, which is practically one-third the value obtained in the present study and closest to the values reported for maize (Table 1). Silva and Acevedo (1995) and Nobel (2003) point out that the roots represent only $12 \%$ of the total biomass of Opuntia ficus-indica, which coincides with our results $(12.48 \% \pm 3.59$, data not shown). After including $12 \%$ of the root biomass in the estimation of $w$ by Felker and Han (1997), $w$ increases up to $6.91 \mathrm{~g} \mathrm{~kg}^{-1}$, showing that the lack of root biomass in the determination of $w$ in this case does not by itself explain the difference with the result obtained here. We believe that the difference in $w$ could be explained by different species and climatic differences between the test sites and mainly by differences in the estimation of crop transpiration. Silva and Acevedo (1995) determined $w$ for 10 Opuntia taxa in a greenhouse in the same area where this study was performed. They obtained $w$ values ranging from $22.18 \pm$ 2.41 (Opuntia streptacantha) to $54.88 \pm 2.91$ (Opuntia pumila) $\mathrm{g} \mathrm{kg}^{-1}$ (Table 1) for well-watered plants. Specifically, for Opuntia ficus-indica, they obtained values ranging from $40.64 \pm 2.81$ to $49.63 \pm 3.31$ for water-restricted and wellwatered plants, respectively. These values were 2 to 3 times greater than those obtained in this study. This difference could be explained mainly because Silva and Acevedo (1995) carried out their experiments in a greenhouse. They mentioned that the average night temperature and the average relative humidity between July and March were between 15 and $20{ }^{\circ} \mathrm{C}$ and 80 and $90 \%$, respectively. Considering a simple comparative analysis with an average night temperature of $17.5^{\circ} \mathrm{C}$ and a relative humidity close to $90 \%$, the average Dan would be $0.2 \mathrm{KPa}$, which is close to half of the average Dan obtained for the same period in this investigation $(0.39 \mathrm{KPa}$, data not shown). Based on this result, we hypothesize that our plants transpired two times more (Fick's law) than theirs and in turn had a lower w. Accepting this gross relationship when comparing the values of $w$ estimated by Silva and Acevedo (1995) for Opuntia ficus-indica with ours, their values must decrease by half, resulting in $20.32 \mathrm{~g}$ $\mathrm{kg}^{-1}$ and $24.92 \mathrm{~g} \mathrm{~kg}^{-1}$ for water-restricted and wellwatered plants, respectively, which are closer to our results. Furthermore, in certain studies, a low WUE of Opuntia ficus-indica has been reported during the first year of establishment (Ratsele, 2003, Snyman, 2013), while the opposite occurs when the WUE is estimated in older plants (Snyman, 2013). However, the latter was not observed with our results; extrapolating $w$ from the data only from the second season (8-month-old plants, similar to Silva and Acevedo plants) resulted in an even lower $w$ (data not shown). Despite this result, plant age should be a topic to consider for further investigation.
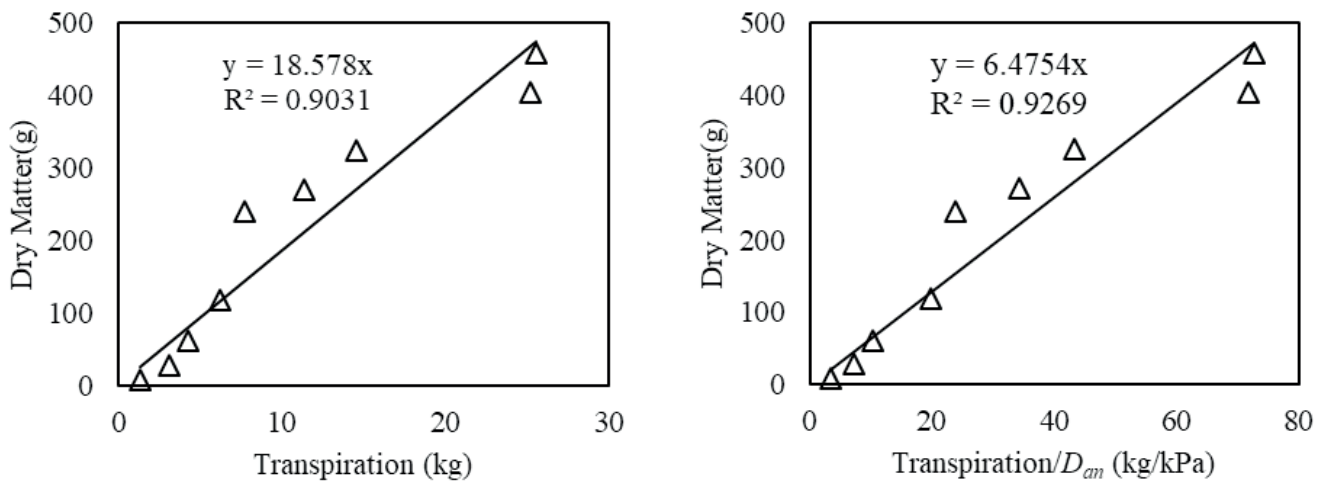

Figure 4. Dry matter as a function of cumulative transpiration (A) and cumulative transpiration normalized by the air vapor pressure deficit at night (B) for cactus pear grown in Las Cardas, Coquimbo Region. 


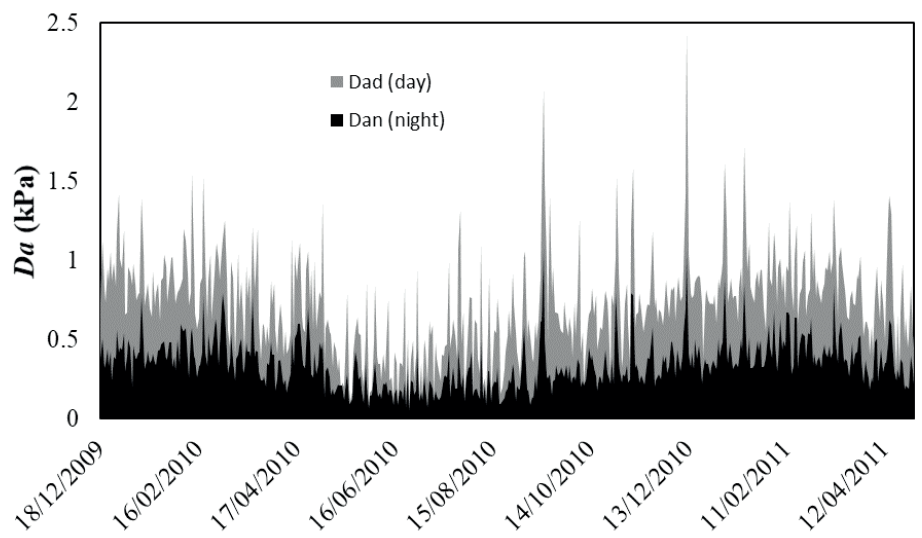

Figure 5. Day (Dad) and night (Dan) vapor pressure deficit $(D a)$.

Table 1. Transpiration-use efficiency $(w)$ and $k_{D a}$ for different species reported or calculated from data obtained from the literature and the present study.

\begin{tabular}{|c|c|c|c|c|c|}
\hline Photosynthetic metabolism & Common name & Species & $w$ & $k_{D a}$ & Source \\
\hline & & & $\mathrm{g} \mathrm{kg}^{-1}$ & $\mathrm{~g} \mathrm{kPa} \mathrm{kg}^{-1}$ & \\
\hline \multirow[t]{3}{*}{$\mathrm{C} 4$} & Maize & Zea mays & $4.12-8.25$ & $6.1-8.4$ & $a^{1,2}$ \\
\hline & & Miscanthus & $11.5-14.2$ & 6.6 & $b^{1}$ \\
\hline & Sorghum & Sorghum bicolor L. & $4.1-4.85$ & $8.6-10$ & $\mathrm{c}^{2}$ \\
\hline \multirow[t]{5}{*}{$\mathrm{C} 3$} & Alfalfa & Medicago sativa & 4.1 & 4.3 & $\mathrm{~d}^{1}$ \\
\hline & Barley & Hordeum vulgare $L$. & $3.2-5.69$ & $3.0-6.9$ & $\mathrm{e}^{1,2}$ \\
\hline & Wheat & Triticum aestivum $L$ & $3.1-8.61$ & $2.7-5.9$ & $\mathrm{f}^{1,2}$ \\
\hline & Rice & Oryza sativa $L$. & $2.2-4.0$ & $1.3-5.0$ & $g^{1}$ \\
\hline & Jatropha & Jatropha curcas L. & 4.3 & 3.3 & $\mathrm{~h}^{1}$ \\
\hline \multirow[t]{6}{*}{ CAM } & Tuna blanca & O. hyptiacantha & 30.04 & 5.76 & $j^{2,3}$ \\
\hline & Cardella & O. pumila & 54.88 & 10.43 & $j^{2,3}$ \\
\hline & Tuna cardona & O. streptacantha & 31.82 & 9.3 & $j^{2,3}$ \\
\hline & Nopal cochinero & O. cochinillifera & 35.73 & 6.04 & $j^{2,3}$ \\
\hline & Nopal & O. ficus indica & 49.63 & 9.42 & $j^{2,3}$ \\
\hline & Nopal & O. ficus indica & 18.58 & 6.5 & $\mathrm{k}^{1}$ \\
\hline
\end{tabular}

a: Tanner and Sinclair, 1983; Howell et al., 1988; Kremer et al., 2015; b: Clifton-Brown and Lewandowski, 2000; c: Thapa et al (2017); d: Tanner and Sinclair (1983); e: Kemanian et al (2005); f: Kemanian et al (2005); Kremer et al., (2015); g: Haefele et al (2009); h: Kremer et al., (2020); j: Silva and Acevedo (1995); k: present research. $1 w$ and $k_{D a}$ were estimated with the same methodology used in the present research, $2 w$ and $k_{D a}$ were estimated considering total crop transpiration and biomass for the whole period, and $D_{a}$ is the average for the same period, according to (Kemanian et al., 2005), and 3 for $k_{D a}$, an average Dan of $0.2 \mathrm{KPa}$ was utilized.

Normalized water-use efficiency $\left(k_{D a}\right)$ has been widely reported in cereals. However, there is little information on CAM plants (Table 1). We are the first study that explicitly presents $k_{D a}$ for Opuntia ficus-indica, which was $6.48 \pm 0.85 \mathrm{~g}$ $\mathrm{kPa} \mathrm{kg}^{-1}$. The relevance of this parameter is related to the close link between $w$ and $D_{a}$ (Vadez et al., 2014). Consequently, normalization by
$D_{a}$ is fundamental to be able to compare $w$ in different climatic zones and periods of the year and to estimate biomass production and water use among zones. In this sense, as observed by Kemanian et al. (2005) in barley, normalization by $D_{a}$ decreased the dispersion of the data (Figure 3). The $k_{D a}$ value obtained for cactus pear in this study was larger, and the values for alfalfa, 
rice, and jatropha were surprisingly close to the highest values for wheat and barley (Table 1, C3 plants). In a comparison with $\mathrm{C} 4$ plants, $k_{D a}$ fell in the lower range of values for Zea mays, was similar to values for Miscanthus, and was less than values for Sorghum bicolor L. It is interesting to note that our $k_{D a}$ value falls in the lowest $k_{D a}$ range inferred from Silva and Acevedo (1995) for Opuntia taxa (Table 1), and as happened in the analysis of $w$ in the case of Opuntia ficus-indica, their value is still higher than that obtained here. The reasons that may explain these differences are the same as those mentioned to explain $w$. Table 1 shows the impact of climate on the estimation of $w$ and how normalization by a variable such as $D a$ allows this impact to be moderated and values obtained in different regions through $k_{D a}$ to be more comparable. A clear example of this is the comparison of $w$ in the higher range of Zea mays (8.25 $\mathrm{g} \mathrm{KPa} \mathrm{kg}^{-1}$ ) with the value obtained for Opuntia ficus-indica in this study $(18.58 \mathrm{~g}$ $\mathrm{KPa} \mathrm{kg}{ }^{-1}$ ). Initially, one would choose Opuntia as the more efficient plant; however, when the climate effect is included in the determination of $w$ through the use of $k_{D a}$, both species have a more similar $w$ value. These results are somewhat contradictory to Nobel's (2003) comments on $w$ comparisons among $\mathrm{C} 3, \mathrm{C} 4$ and CAM plants. We expected to obtain larger values, at least those in the higher $\mathrm{C} 4$ range (Table 1), which is closer to the $k_{D a}$ values inferred for Opuntia ficus-indica by Silva and Acevedo (1995). Different authors have mentioned that although $k_{D a}$ is a more reliable and transferable parameter to estimate $w$, it is also influenced by climatic conditions (Kemanian et al., 2005, Steduto \& Albrizio, 2005, Kremer \& Stockle., 2012). Therefore, more research is needed on the estimation of $k_{D a}$ in different agroclimatic conditions and in later stages of development to increase the database for comparison.

\section{Conclusions}

The values for transpiration-use efficiency $(w)$ and the normalized water-use efficiency $\left(k_{D a}\right)$ for young cactus pear were $18.58 \mathrm{~g} \mathrm{~kg}^{-1}$ and $6.48 \mathrm{~g}$ $\mathrm{kg}^{-1}$, respectively. The $w$ value was within the ranges for CAM plants inferred from previous studies and was high enough for use in cactus pear under semiarid conditions, as an alternative to $\mathrm{C} 3$ plants. However, when $k_{D a}$ was compared with values for $\mathrm{C} 4$ plants, it fell within their lower range. This is the first study that explicitly determined $k_{D a}$ for Opuntia ficus-indica; therefore, more research should be carried out on the estimation of $w$ and $k_{D a}$ including under different agroclimatic conditions and during later stages of development of the crop, which will allow more confidence in the range of variation of these parameters. We are confident that the parameters obtained here can be used as a first approximation to estimate yield projections of Opuntia ficus-indica.

\section{Resumen}

C. Kremer, C. Faúndez, V. Beyá-Marshall, N. Franck, y V. Muñoz-Aravena. 2021. Eficiencia de uso de la transpiración en plantas jóvenes de nopal (Opuntia ficus-indica L.). Int. J. Agric. Nat. Resour. 115-124. Opuntia ficus-indica es un cultivo versátil, resistente a la sequía, ideal para zonas semiáridas y áridas. Sin embargo, la falta de conocimiento de sus beneficiosos usos y la falta de modelos de crecimiento para estimar su potencial, entre otros, ha impedido su expansión. La eficiencia de uso de la transpiración $(w)$ se ha utilizado para evaluar el rendimiento de los cultivos con diferentes suministros de agua. Sin embargo, la falta de consistencia de $w$ en diferentes condiciones ambientales ha impedido su uso como parámetro transferible. Para superar esto, $w$ se estima a través de la eficiencia de uso de agua normalizada $\left(k_{D a}\right)$ y el déficit de presión de vapor $(D a)$ como; $w=k_{D a} D a^{-1}$, donde $k_{D a}$ es un parámetro dependiente del cultivo. Por lo tanto, los objetivos fueron (i) determinar $w y k_{D a}$ en 
plantas jóvenes de Opuntia ficus-indica y (ii) comparar estos con valores de otras especies. Los resultados de $w$ y $k_{D a}$ fueron $18.57 \mathrm{~g} \mathrm{~kg}^{-1}$ y $6.48 \mathrm{~g} \mathrm{kPa} \mathrm{kg}^{-1}$, respectivamente. $w$ excedió de dos a seis veces el valor de los cereales tradicionales (maíz, arroz, trigo); mientras que $k_{D a}$ fue mayor que la mayoría de los cultivos C3 y cayó en el rango de los cultivos C4 y CAM. Este es el primer estudio que determina $k_{D a}$ para Opuntia ficus-indica, por lo que se deben realizar más investigación incluyendo diferentes condiciones agroclimáticas y etapas posteriores de desarrollo. Los parámetros obtenidos se pueden utilizar como un modelo simple para estimar las proyecciones de rendimiento de Opuntia ficus-indica.

Palabras claves: Agricultura de zonas áridas, CAM, cultivos adaptados a la sequía, modelos simples de crecimiento de cultivos.

\section{References}

Bernab, M., \& Lamas, C. (2011). Aptitud agroclimática de áreas áridas y semiáridas de Argentina para el cultivo de tuna (Opuntia ficus indica) como fuente de bioetanol. Quebracho - Revista de Ciencias Forestales, 19, 66-74.

Carvajal ,M., Mota, C., Alcaraz-López, C., Iglesias, M., \& Ballesta, M. (2010). Investigación sobre la absorción de CO2 por los cultivos más representativos de la región de Murcia. Departamento de Nutrición Vegetal. CEBAS-Consejo Superior de Investigaciones Científicas. 30100-Espinardo Murcia España: 8-10.

Clifton-Brown, J., \& Lewandowski, I. (2000). Water use efficiency and biomass partitioning of three different Miscanthus genotypes with limited and unlimited water supply. Annals of Botany, 86, 191-200. https://doi.org/10.1006/ anbo. 2000.1183

Condon, A.G., Richards,R.A., \& Farquhar, G.D. (1993). Relationships between Carbon Isotope Discrimination, Water Use Efficiency and Transpiration Efficiency for Dryland Wheat. Australian Journal of Agricultural Research 44, 1693-1711.

Garreaud, R., Alvarez-Garreton, C., Barichivich, J., Boisier, J.P., Christie, D., Galleguillos, M., LeQuesne, C., McPhee, J., \& Zambrano-Bigiarini, M. (2017). The 2010-2015 mega drought in Central Chile: Impacts on regional hydroclimate and vegetation. Hydrolgy and Earth System Sciences Discussion, 98, 1-37.
Felker. P., \& Han, H. (1997). Field validation of water-use efficiency of the CAM plant Opuntia ellisiana in south Texas. Journal of Arid Environoments, 36,133-148.

Haefele, S., Siopongco, J., Boling, A., Bouman, B., \& Tuong, T. (2009). Transpiration efficiency of rice (Oryza sativa L.). Field Crops Research, 111, 1-10. doi: 10.1016/j.fcr.2008.09.008

Howell, T., Tolk, J., Schneider, A., \& Evett, S. (1988). Evapotranspiration, yield and water use efficiency of corn hybrids differing in maturity. Agronomy Journal, 90, 3-9. doi: 10.2134/agronj 1998.00021962009000010002x

Inglese, P., Mondragon., C, Nefzaoui, A.S., \& Saenz, C. (2017). Crop Ecology, cultivation and uses of Cactus Pear. FAO. Rome, Italy.

Katerji, N., Mastrorilli, M., \& Rana, G. (2008). Water use efficiency of crops cultivated in the Mediterranean region: Review and analysis. European Journal of Agronomy, 28, 493-507. doi: 10.1016/j.eja.2007.12.003

Kemanian, A., Söckle, C., \& Huggins, D. (2005). Transpiration-use efficiency of barley. Agricultural Forest and Meteorology, 130,1-11. doi: 10.1016/j.agrformet.2005.01.003

Kremer, C., Stockle, C., Kemanian, A., \& Howell, T. (2008). A reference canopy transpiration and photosynthesis model for the evaluation of simple models of crop productivity. L.R Ahuja, V.R. Reedy, and Qiang Yu (Ed). Advances in agricultural system Modeling 1. Response of Crops to Limited Water: Understanding and modeling water stress effects on plant growth 
processes (pp. 165-189). American society of Agronomy.

Kremer, C., Homer, I., Haberland, J., \& García de Cortazar, V. (2015). Evaluation of simulationbased methods for estimating transpiration-use efficiency of wheat and maize. International Journal of Science, Environment and Technology, 4, 73-85.

Kremer, C., Parada, F., Homer, I., \& Seguel, O. (2020). Eficiencia del agua transpirada $(w)$ y normalizada $\left(k_{D a}\right)$ en plantas jóvenes de Jatropha (Jatropha Curcas L.) en la región de Coquimbo, Chile. IDESIA, 38(4), 65-72.

Kremer, C., \& Stöckle C.O.(2012). Assesing the transferability of transpiration-use efficiency models of biomass production. Chilean Journal of Agricultural Research 72, 10-15.

Nobel, P. (2003) Eco fisiología de Opuntia ficus-indica. Rome, Italy.

Ratsele, C. (2003). Production evaluation of Opuntia robusta and $O$. ficus-indica cultivars in the Central Free State. M.Sc.-thesis University of the Free State, Bloemfontein, South Africa.

Sáenz, C., Berger, H., Corrales, J., García, J., Galletti, L., García de Cortázar, V., Higuera, I., Mondragón, C., Rodríguez, A., Sepúlveda, E., \& Varnero, M. (2006). Utilización agroindustrial del nopal. Rome, Italy.

Silva, H., \& Acevedo, E. (1995). Eficiencia en el uso del agua de diez taxa de Opuntia introducidas en la región mediterránea de Chile. Revista Chilena de Historia Natural, 68, 271-282.

Snyman, H. (2013). Growth rate and wateruse efficiency of cactus pears Opuntia ficus-indica and O. robusta . Arid Land Research Management, 27,(4), 337-348. doi: 10.1080/15324982.2013.771232

Steduto, P., \& Albrizio, R. (2005). Resource use efficiency of field-grown sunflower, sorghum, wheat and chickpea. II. Water use efficiency and comparison with radiation use efficiency. Agricultural and Forestal Meteorology, 130, 269-281

Sudzuki, F., Muñoz, C., \& Berger, H. (1993). El Cultivo de la Tuna. Santiago-Chile, Departamento de Producción Agrícola Universidad de Chile.

Tanner, C. \& Sinclair, T. (1983). Efficient water use in crop production: research or re-search? In: H. Taylor, W. Jordan \& T. Sinclair (Eds.), Limitations to Efficient Water Use in Crop Production (pp 1-25).Wisconsin, USA.

Thapa, S., Stewart, B., \& Xue, Q. (2017). Grain sorghum transpiration efficiency at different growth stages. Plant Soil Environment, 63, 70-75. doi: 10.17221/796/2016-PSE

Vadez, V., Kholova, J., Medina, S., Kakkera, A., \& Anderberg, H. (2014). Transpiration efficiency: new insights into an old story. Journal of Experimental Botany, 65 (21), 6141-6153. doi. org/10.1093/jxb/eru040

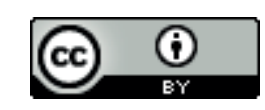

This work is licensed under a Creative Commons Attribution 4.0 International License. 